\title{
Using Simulation to Develop Clinical Nursing Faculty Teaching of Ethics: A Pilot Project
}

\author{
Cynthia S. Randall ${ }^{1}$, Carla E. Randall ${ }^{2}$ \\ ${ }^{1}$ School of Nursing, University of Southern Maine, Portland, ME, USA \\ ${ }^{2}$ School of Nursing, University of Southern Maine, Lewiston, ME, USA \\ Correspondence: Cynthia S. Randall, School of Nursing, University of Southern Maine, Portland, ME, 04104, USA.
}

Received: July 20, 2021

Accepted: August 17, 2021

Online Published: August 21, 2021

doi: 10.11114 jets.v9i8.5333

URL: https://doi.org/10.11114/jets.v9i8.5333

\begin{abstract}
Objective: The purpose of this study was to understand the experiences of clinical instructors participating in a simulated experience teaching ethics.

Background: Teaching ethics is an essential role of the clinical instructor. Limited information exists to guide instructors in the teaching of ethics in clinical settings. Clinical nursing instructors are often hired based on their experience as clinicians and are underprepared to teach ethics to nursing students during clinical instruction.

Methods: A qualitative descriptive interpretive approach was used to understand the experiences of clinical faculty who participated in simulation based learning activities that explored ways to include ethics in clinical teaching. A video, case studies, and role-playing provided an opportunity to practice responding to teaching challenges and explored strategies for guiding ethical learning in clinical teaching.
\end{abstract}

Results: Participants realized that ethics could be integrated into clinical teaching and seeking out ethical discussions with students is as important as teaching other nursing skills.

Conclusions: Using simulation based education is a means to prepare faculty to include ethics in clinical instruction.

Keywords: nursing education, clinical faculty, faculty development, ethics, clinical teaching

\section{Background}

\subsection{Introduction}

Ethical knowledge is crucial to the discipline of nursing and considered foundational knowledge for nursing practice (American Association of Colleges of Nursing [AACN], 2008; AACN, 2021; American Nurses Association [ANA], 2015). An essential role of the clinical instructor is to guide and assist in the ethical formation of nurses (Benner, Sutphen, Leonard \& Day, 2010). In their observations of nursing students, Erdil and Korkmaz (2009) found there was limited information available to guide the application of ethics in the clinical environment. Teaching ethics during clinical instruction provides opportunities to turn knowledge, skills, and attitudes from the classroom into experiential ethical learning for nursing students (Benner et al., 2010).

\subsection{Underprepared for Clinical Teaching}

Due to a national shortage of faculty (AACN, 2019), schools of nursing rely on instructors who have limited preparation for their role as educators (Oermann, 2017). In many programs, staff nurses enter the clinical instructor role underprepared for teaching and how to guide students' learning in clinical settings (Gaberson, Oermann \& Shellenbarger, 2015; Cangelosi, Crocker \& Sorrell, 2009; Davidson \& Rouke, 2012). "Excellence in clinical teaching is not intuitive and successful development in the faculty role does not simply happen" (Phillips, Bassell \& Fillmore, 2019, p. 47). Despite this awareness, clinical instructors report inadequacy regarding the orientation process in preparing them for their faculty role (Dunphy Suplee, Gardner \& Jerome-D’Emilia, 2014; Roberts, Christmann \& Flowers, 2013). The use of simulation as a teaching method used with clinical instructors for faculty development can address the limited preparation for teaching ethical formation (Shellenbarger \& Edwards, 2012). 


\subsection{Use of Simulation as a Learning Strategy}

Although simulation has been readily adopted in nursing programs and is used extensively to teach nursing students, it has not been widely used as a learning tool to develop skills of clinical instructors (Alexander et al., 2015; Hunt, Curtis \& Gore, 2015). Utilizing videos, case studies, and role-playing to create real-like situations provides an interactive learning environment and is a form of simulation (Jeffries, 2012; Ulrich, Gillespie, Boesch, Bateman \& Grubb, 2017). Using simulation to prepare clinical instructors has been identified as an innovative and effective learning strategy (Shellenbarger \& Edwards, 2012; Hunt et al., 2015; Forcina Hill, Woodley \& Goodwin, 2018).

\subsection{Purpose of the Project}

Clinical nursing instructors are often hired based on their experience as clinicians, however, their preparation to teach ethics in this role has not been well established (Numminen \& Leino-Kilpi, 2007; Borhani, Allahani, Mohammedi \& Abbaszadeh, 2010). This Doctorate of Nursing Practice (DNP) project sought to understand the experiences of clinical faculty who participated in a faculty development workshop that explored ways to include ethics in clinical teaching.

\section{Methods}

A qualitative descriptive interpretive approach (Holstein \& Gubrium, 1994; Denzin \& Lincoln, 1994) was used to understand the experiences of clinical instructors participating in simulation based learning activities. The project received the university's institutional review board approval prior to implementation. Responses during the structured debriefings were audio-recorded and transcribed by a third party.

\subsection{Participants}

Participants were clinical instructors $(N=8)$ teaching for a state funded school of nursing in New England and recruited voluntarily via email. Each participant provided written consent. Eight female participants completed the simulated experience. Most participants ( 6 of 8 ) were $40-49$ years of age (ranging from 40-65 years) and all had obtained a Master's degree in Nursing; 4 participants had less than 2 years teaching experience and 4 had greater than 5 years of experience (Randall, 2015). The number of years teaching clinical practice ranged from less than 2 years to greater than 10 years and 3 participants had taken graduate nursing education courses (Randall, 2015). Five participants reported "some to moderate" undergraduate education in ethics while only 1 participant reported "some" graduate education in ethics. Four reported "some" experience teaching ethics and encountering ethical situations during clinical instruction (Randall, 2015).

\subsection{Intervention}

Once recruited, participants were sent a 10 minute slideshow lecture podcast that included a brief review of terms and general knowledge on ethics as a content refresher. For the simulation activities, INACSL Standards of Best Practice: Simulation (C (2016) were followed. Participants were pre-briefed, which included: a review of the learning outcomes, information on participant roles, and the structured debriefing process. Participants were shown a 5 minute video of an ethical clinical teaching dilemma (Note 1). The video showed a nursing student experiencing moral distress during the insertion of an indwelling urinary catheter. The student contaminated the catheter and was told by the staff nurse to go ahead and reinsert the catheter since the patient had already been started on antibiotics. After viewing the video, participants explored responses to the situation as the clinical instructor.

Additionally, participants role-played responses to four ethical case studies developed by the facilitator to address principles of respect, human dignity, self-determination, and fidelity. The case studies addressed responses of nurses (in the presence of a student) regarding a psychiatric patient, a religious diet restriction related to a scheduled medication, a deception of giving saline rather than pain medication, and a patient's need for dependence vs independence. Participants role-played, as the clinical instructor, how they would respond to the different ethical case studies. A structured debriefing followed each role-play scenario using Dreifuerst's (2012) Debriefing for Meaningful Learning (DML). The DML method has been shown to be an effective tool that fosters meaningful learning by encouraging participants to reflect in and on action (Bradley, 2019; Dreifuerst, 2012).

\section{Results}

\subsection{Participants' Reflections}

\subsubsection{Role Modeling Ethical Practice}

Regarding student learning, participants discussed that role modeling ethical practice for students was considered an important function of teaching. Participants recognized the value of maximizing opportunities for role-modeling ethical responses during clinical instruction. One participant commented, "they [students] look up to you as a role model, it is important to do and say the right thing." Participants recognized that moving to engage students in difficult ethical conversations can be uncomfortable. "[I was] being in a place of discomfort", and "[I was] quite challenged" to come up 
with effective responses in the moment and "students expect you to engage in those difficult conversations." One participant noted that teaching ethical skills "was as important to student learning as compared to other nursing skills." Empowering students to perform the right action, give a moral response, and use effective communication skills in the moment were concepts significant to all participants.

\subsubsection{Responsibility to Teach Ethics}

In reflecting on how the simulated experience impacted their learning, participants reported becoming more aware of their role and "responsibility to teach ethics during clinical instruction." "I would like to be more intentional about incorporating ethics and responses in our seminar discussion/post-clinical debriefing" and more importantly "to try to include more ethical teaching in the clinical setting." The role-playing activities, "helps me think through my own responses." Another participant reported, "I learned great 'on the spot'responses and redirects" and "... these simulations occur in real life and practicing how to respond to them is important." The debriefing experiences "... helped to consider the balancing act and the importance of communication, clarification, and negotiation as we promote student learning and advocate for students." Participants concluded that "finding opportunities to practice this skill" was significant in stimulating ways to incorporate ethics into clinical teaching.

\subsubsection{Learning Curve to Teaching Ethics}

Participants acknowledged there is a learning curve in the teaching and learning of ethics. "It takes significant skill [to navigate ethical dilemmas] for the clinical instructor." In response to the role-playing activities, "as the instructor, I did not know what to say ... I couldn't react", "we were all kind of pondering ... how would we, as a clinical instructor, respond." "I can do fact finding ... but I am not good at the next step [in teaching ethics]." There was a tendency to "avoid conflicts with staff" and felt obligated to remain "non-confrontational." One participant "... felt like I wanted to whisk my student away from the situation and not react in a big way because the nurse was being really inappropriate."

\section{Discussion}

Realistic clinical situations of ethical dilemmas provided a unique opportunity for participants to practice responses and explore teaching strategies for coaching and guiding students in ethical learning. Simulation based learning activities provided for rich discussion of ways to include the concept of ethics in clinical teaching. Role-playing real-like situations allowed participants to feel the emotions they would experience should they encounter a similar situation in the future (Ulrich et al., 2017). There was evidence that active role-playing allowed for problem-solving, decision-making (Jeffries, 2012), and the exploration of emotions while responding in the moment was similar to research reported by Ulrich et al., (2017).

Scenarios in ethical dilemmas can be developed that create opportunities for high stakes, low-frequency practice situations. Using ethics as an exemplar, provided an experience for participants to respond to challenging teaching situations that moved beyond the routine and familiar nursing skills. The activity offered an approach for faculty development which typically does not exist beyond basic orientation for clinical instructors (Dunphy Suplee et al., 2014). Offering opportunities for clinical instructors to practice teaching ethics during clinical experiences is crucial to prioritize ethical formation (Benner et al., 2010). By addressing the preparation and development of clinical instructors' teaching of ethics aligns with strengthening the ethical foundation of new nurses (Rushton, Broome \& Nursing Ethics for the 21st Century Summit Group, 2014; Institute of Medicine, 2011).

\section{Conclusion}

Simulation experiences to prepare clinical instructors for their role in teaching ethics poses a new opportunity for simulation based education in faculty development. Simulation based education, using low-fidelity methods of video and case studies to promote role-playing with a structured debriefing, is simple to create and does not require a simulation center with advanced levels of technology or staff. Improving clinical instruction using simulation methods is an effective innovation and many opportunities exist for ongoing research in this area. This DNP project identified a need to develop the clinical instructor's role in teaching ethics and demonstrated that using simulated experiences can promote that learning. The findings from this project supports evidence found in Hunt et al., (2015) and Shellenbarger and Edwards (2012) that simulated experiences can be utilized with clinical instructors to develop their teaching practice.

\section{Conflicts of Interest}

The authors declare no conflicts of interest regarding the publication of this paper

\section{Funding}

No funding was received for this research project 


\section{References}

Alexander, M., Durham, C., Hooper, J., Jeffries, P., Goldman, N., Kardong-Edgren, S., Kesten, K., Spector, N., Tagliareni, E., Radtke, B., \& Tillman, C. (2015). NCSBN simulation guidelines for pre-licensure nursing programs. Journal of Nursing Regulations, 6(3), 39-42. https://doi.org/10.1016/S2155-8256(15)30783-3

American Association of Colleges of Nursing. (2008). The Essentials of Baccalaureate Education for Professional $\begin{array}{llllll}\text { Nursing } & \text { Practice. } & \text { Retrieved } & \text { February } & \text { 5, 2020, }\end{array}$ http://www.aacn.nche.edu/education-resources/baccessentials08.pdf

American Association of Colleges of Nursing. (2019). Nursing Faculty Shortage Fact Sheet, Retrieved January 10, 2021, from https://www.aacnnursing.org/news-information/fact-sheets/nursing-faculty-shortage

American Association of Colleges of Nursing. (2021). The Essentials: Core Competencies for Professional Nursing Education. Retrieved June 10, 2021, from https://www.aacnnursing.org/Portals/42/AcademicNursing/pdf/Essentials-2021.pdf

American Nurses Association. (2015). Code of ethics for nurses with interpretive statements. Retrieved January 10, 2020, from https://www.nursingworld.org/practice-policy/nursing-excellemce/ethics/code-of-ethics-for-nurses/coe-view-only/

Benner, P., Sutphen, M., Leonard, V., \& Day, L. (2010). Educating nurses: A call for radical transformation. Jossey-Bass.

Borhani, F., Alhani, F., Mohammedi, E., \& Abbaszadeh, A. (2010). Professional ethical competence in nursing: The role of nursing instructors. Journal of Medical Ethics and History of Medicine, 3(3).

Bradley, C. S. (2019). Impact of training on use of debriefing for meaningful learning. Clinical Simulation in Nursing, 32 , 13-19. Retrieved from https://doi.org/10.1016/j.ecns.2019.04.003

Cangelosi, P., Crocker, S., \& Sorrell, J. (2009). Expert to novice: Clinicians learning new roles as a clinical nurse educator. Nursing Education Perspectives, 30(6), 367-371.

Davidson, K., \& Rourke, L. (2012). Surveying the orientation learning needs of clinical nursing instructors. International Journal of Nursing Education Scholarship, 9(1), 1-11. https://doi.org/10.1515/1548-923X.2314

Denzin, N. K., \& Lincoln, Y. S. (1994). Handbook of qualitative research. Sage.

Dreifuerst, K. (2012). Using debriefing for meaningful learning to foster development of clinical reasoning in simulation. Journal of Nursing Education, 51(6), 326-333. https://doi.org/10.3928/01484834-20120409-02

Dunphy-Suplee, P., Gardner, M., \& Jerome-D’Emilia, B. (2014). Nursing faculty preparedness for clinical teaching. Journal of Nursing Education, 53(3), S38-S41. https://doi.org/10.3928/01484834-20140217-03

Erdil, F., \& Korkmaz, F. (2009). Ethical problems observed by student nurses. Nursing Ethics, 16(5), 589-598. https://doi.org/10.1177/0969733009106651

Forcina Hill, J., Woodley, L., \& Goodwin, M. (2018). Simulation to prepare graduate nursing students for clinical faculty role. Nursing Education Perspective, 39(5), 319-321. https://doi.org/10.1097/01.NEP.0000000000000304

Gaberson, K. B., Oermann, M. H., \& Shellenbarger, T. (2015). Clinical teaching strategies in nursing (4th ed.). Springer.

Holstein, J. A., \& Gubrium, J. F. (1994). Phenomenology, ethnomethodology, and interpretive practice. In N. K. Denzin and Y. S. Lincoln (Eds.), Handbook of qualitative research (pp. 262-272). Sage.

Hunt, C., Curtis, A., \& Gore, T. (2015). Using simulation to promote professional development of clinical instructors. Journal of Nursing Education, 54(8), 468-471. https://doi.org/10.3928/01484834-20150717-09

Institute of Medicine. (2011). The future of nursing: Leading change, advancing health. The National Academies Press.

International Nursing Association for Clinical Simulation and Learning. (2016). Standards of Best Practice: Simulation C. Retrieved February 5, 2020, from https:/www.inacsl.org/inacsl-standards-ofbest-practice-simulation/

Jeffries, P. (2012). Simulation in nursing education: From conceptualization to evaluation (2 ${ }^{\text {nd }}$ ed.). National League of Nursing.

Numminen, O. H., \& Leino-Kilpi, H. (2007). Nursing students' ethical decision-making: A review of the literature. Nurse Educator Today, 27, 796-807. https://doi.org/10.1016/j.nedt.2006.10.013

Oermann, M. (2017). Preparing nurse faculty. It's for everyone. Nurse Educator, 42(1). https://doi.org/10.1097/NNE.0000000000000345

Phillips, C., Bassell, K., \& Fillmore, L. (2019). Transforming nursing education through clinical faculty development. 
Teaching and Learning in Nursing, 14;47-53. Retrieved from https://doi.org/10.1016/j.teln.2018.09.007

Randall, C., (2015). A simulation to improve the clinical nursing instructor's teaching of ethics to students in the clinical setting, All Theses \& Dissertations. 296. Retrieved from https://digitalcommons.usm.maine.edu/etd/296

Roberts, K., Chrisman, S., \& Flowers, C. (2013). The perceived needs of nursing clinicians as they move into an adjunct clinical faculty role. Journal of Professional Nursing, 29(5), 295-301. https://doi.org/10.1016/j.profnurs.2012.10.012

Rushton, C. H., Broome, M., \& The Nursing Ethics for the 21st Century Summit Group. (2014). A Blueprint for 21st Century Nursing Ethics: Report of the National Nursing Summit. Retrieved from $\mathrm{http} / / / \mathrm{www}$. bioethicsinstitute.org/nursing-ethics-summit-report

Shellenbarger, T., \& Edwards, T. (2012). Nurse educator simulation: Preparing faculty for clinical nurse educator roles. Clinical Simulation in Nursing. https://doi.org/10.1016/j.ecns.2010.12.006

Ulrich, D., Gillespie, G., Boesch, K., Bateman, K., \& Grubb P. (2017). Reflective responses following a role-play simulation of nurse bullying. Nursing Education Perspectives, $38(4)$. https://doi.org/10.1097/01.NEP.0000000000000144

\section{Notes}

Note 1 . The video used was made by a colleague and graduate students for another purpose.

\section{Copyrights}

Copyright for this article is retained by the author(s), with first publication rights granted to the journal.

This is an open-access article distributed under the terms and conditions of the Creative Commons Attribution license which permits unrestricted use, distribution, and reproduction in any medium, provided the original work is properly cited. 